\title{
Impact of the Barents Sea SST in Autumn on the Winter Climate in Northeast China
}

\author{
Xiaomeng Shi ${ }^{*}$, Yu Gu², Jilin Sun², Jingshu Dong3, Min Geng1 \\ ${ }^{1}$ Qingdao Engineering Technology Research Center for Meteorological Disaster Prevention, Qingdao Meteorological Bureau, \\ Qingdao, China \\ ${ }^{2}$ Physical Oceanography Laboratory, Ocean-Atmosphere Interaction and Climate Laboratory, Ocean University of China, \\ Qingdao, China \\ ${ }^{3}$ CMA Public Meteorological Service Center, Beijing, China
}

Email: *shi198710@126.com

How to cite this paper: Shi, X.M., Gu, Y., Sun, J.L., Dong, J.S. and Geng, M. (2017) Impact of the Barents Sea SST in Autumn on the Winter Climate in Northeast China. Journal of Geoscience and Environment Protection, 5, 89-95.

https://doi.org/10.4236/gep.2017.57009

Received: May 16, 2017

Accepted: July 11, 2017

Published: July 14, 2017

Copyright $\odot 2017$ by authors and Scientific Research Publishing Inc. This work is licensed under the Creative Commons Attribution International License (CC BY 4.0).

http://creativecommons.org/licenses/by/4.0/

\begin{abstract}
We studied effects of sea surface temperature anomaly (SSTA) in the Barents Sea in autumn on the atmospheric circulation in northeast China in winter, using the NCEP reanalysis data and sea surface temperature (SST) data of the Hadley Center. The results show that the ocean thermal conditions in the Barents Sea in autumn can be used as an important reference factor for predicting the cold air activity in China. When the sea surface temperature anomaly of the Barents Sea elevated in the autumn, the sea-level pressure anomaly elevated in eastern China on December, northeast China and southeastern Russia on January and February. In the years when the SSTA of the Barents Sea elevated in the autumn, the abnormal high-pressure ridge developed over Europe, and the geopotential height in western China appeared negative anomaly at $500 \mathrm{hPa}$. At $1000 \mathrm{hPa}$, the Mongolia high-pressure increased and the northerly airflow strengthened the cold high-latitude air broke out to the south, which was easy to affect northeast and north of China. In negative SSTA years, the high-pressure ridge was west to the north Atlantic, and the geopotential height in central and northern Siberia appeared negative anomaly at $500 \mathrm{hPa}$; the Mongolia high-pressure was weakened at $1000 \mathrm{hPa}$.
\end{abstract}

\section{Keywords}

Autumn, the Barents Sea, SSTA, Atmospheric Circulation

\section{Introduction}

Ocean is an important source of forcing the anomalous change of atmospheric circulation. Ocean thermal effect has an important influence on the study of climate change theory and climate prediction by influencing the atmospheric 
circulation anomaly [1]. In the study of long-term sea-air interaction, a series of studies on climate in China for the high latitude area have been carried out in high latitudes [2] [3] [4]. The study of air-sea interaction at high latitudes is relatively weak compared with those of the middle and low latitudes, such as how the cold air source sea area affected the circulation and the climate of eastern China, so further study is needed to reveal them.

There are three main sources of cold air influencing China: 1) At north of $70^{\circ} \mathrm{N}$ and west of the Novaya Zemlya, the Barents Sea, the cold air through the Barents Sea, Russia, Europe and other regions entered China, of which the number of times to enter China was the most and the number of cold wave was also the most; the cold air of the source accounted for $40 \%$ in China. 2) In the east of the Novaya Zemlya Ocean, the cold air is mostly through the Kara Sea, Russia into China. 3) At about $60^{\circ} \mathrm{N}$ and south of Iceland ocean [5].

As a source of cold air that was likely to cause strong and frequent impacts on China; the Barents Sea thermal condition affected the winter climate in China by influencing the atmospheric circulation and the cold high-pressure. Wu et al. [6] [7] [8] have carried out extensive and detailed work to suggest that the sea ice area anomaly in the Kerala and Barents Sea in winter can affect the cold highpressure activities on Asian continent in winter and the strength of the winter monsoon in East Asian. Wu et al. [9] found that there is an inverse change between the autumn and winter Arctic sea ice distribution anomaly and the Siberian high-pressure in winter, and there was consistency about the sea ice change between the Greenland Sea and the East-West sea of Novaya Zemlya (Barents Sea and Kara Sea).

However, the work of predecessors was mostly to study the relationship between the ocean thermal conditions and the atmospheric circulation in the same period, and the work on the relationship between the change of oceanic thermal conditions in the Barents Sea and the atmospheric circulation in China was less, which was important to the climate prediction of China in winter. In this paper, we studied the influence of the Barents Sea SST in autumn on climate in eastern China and its mechanism by analyzing the persistence of the Barents Sea SST in autumn and the relationship between the Barents Sea SST in autumn and the sea level pressure, atmospheric circulation in northeast China.

\section{Data and Methods}

The SST field $\left(1^{\circ} \times 1^{\circ}\right)$ was derived from the monthly-mean data of the Hadley Centre for Climate Prediction and Research.

$1000 \mathrm{hPa}$ and $500 \mathrm{hPa}$ geopotential height fields, the sea level pressure field were derived from the monthly-mean data of the National Center for Environmental Prediction and the Center for Atmospheric Research (NCEP/NCAR).

\section{Persistence of Barents Sea SSTA in Autumn}

The persistence of Barents Sea SSTA in autumn is an important condition for the climate prediction by using the Barents Sea Autumn SSTA. Figure 1 shows 

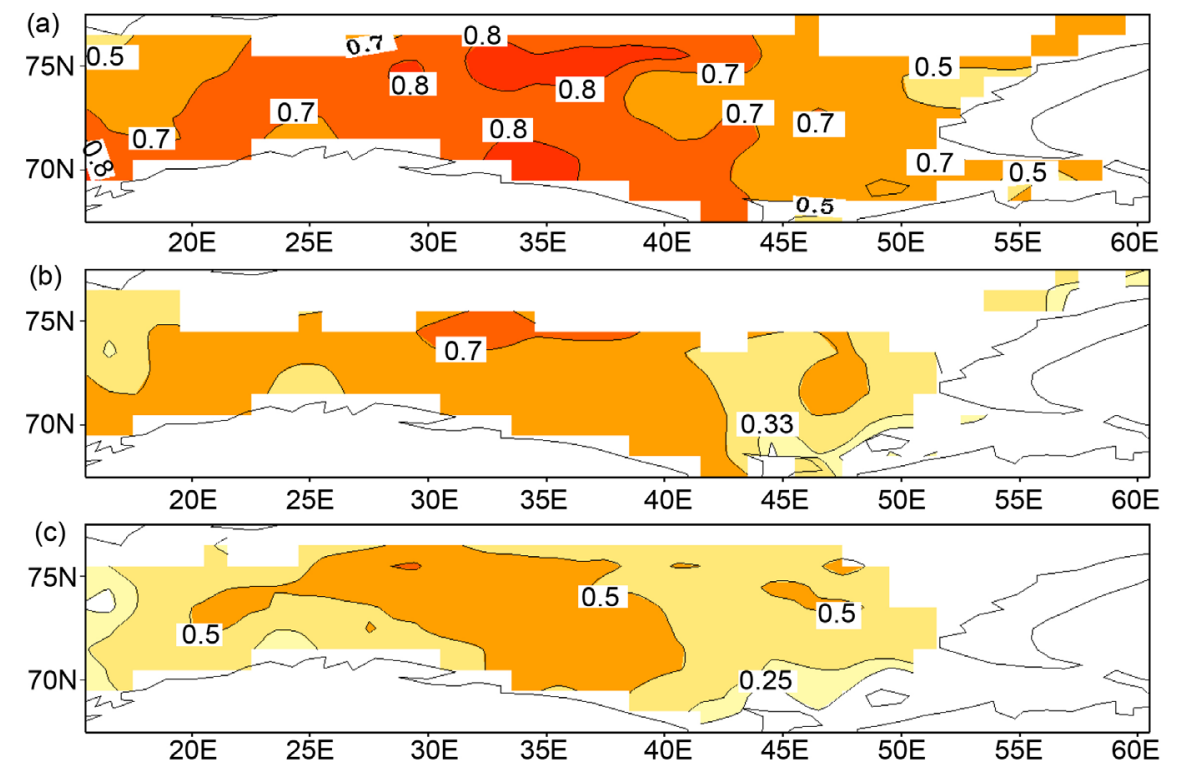

Figure 1. Correlation coefficient between the Barents Sea SSTA in October and the Barents Sea SSTA in (a) November, (b) December, and (c) January in the following year. The shaded area indicates a significant correlation (at $95 \%$ significant level by $\mathrm{t}$-test).

the persistence of Barents Sea SSTA in October $\left(67.5^{\circ}-77.5^{\circ} \mathrm{N}, 15.5^{\circ} \mathrm{E}-60.5^{\circ} \mathrm{E}\right)$. Using $\mathrm{t}$ test, the sea area with correlation coefficient greater than 0.25 was through $95 \%$ significance test, and the sea area with correlation coefficient greater than 0.33 was through $99 \%$ significance test.

Figure 1(a) shows that the SSTA in October has a significant positive correlation with November, and the correlation coefficient is basically through $99 \%$ significance test in the whole sea area. The maximum correlation coefficient is between $70^{\circ} \mathrm{N}-76^{\circ} \mathrm{N}, 20^{\circ} \mathrm{E}-45^{\circ} \mathrm{E}$ region, and the correlation coefficient basically exceeds 0.7 . In Figure 1(b), the SSTA in the southern and southern Barents Sea has good persistence. In Figure 1(c), the SSTA in October has a significant positive correlation with the following January, and the SST in central Barents Sea has good persistence until January of the following year. Similarly, there was a significant positive correlation between SSTA in October and SSTA during February to May of the following year (figures are omitted). It can be seen that the SSTA of the Barents Sea has good persistence in early October and can continue until late spring.

\section{Relationship between the Barents Sea SSTA in Autumn and Atmospheric Circulation in NE China Winter}

\subsection{Relationship between the Barents Sea SSTA in Autumn and SLPA in NE China Winter}

In order to investigate the relationship between the Barents Sea SST in autumn and the cold air activity in the eastern and offshore China, selecting the SSTA field of the Barents Sea in autumn (September, October and November) and SLPA in the eastern part of China in winter (December, January and February) to do SVD analysis. 
In Figure 2, the sea area with correlation coefficient greater than 0.3 and 0.38 were through the $95 \%$ and $99 \%$ reliability test. The correlation coefficients of the two modes correspond to the first modal time coefficients were $0.53,0.4$ and 0.54. In Figure 2(a), the key region was in the north of the Barents Sea (positive correlation). In Figure 2(b), there was a broad range of positive correlations, and the most significant region was in the southeast coast of China. The key area in Figure 2(c) was in the west-central Barents Sea (positive correlation). Figure 2 (d) shows, and the most significant area is in northeast China. The key regions in Figure 2(e) was in the north of the Barents Sea (negative correlation), the southern waters (positive correlation). Figure $2(\mathrm{f})$ shows the large-scale positive correlation. In general, when the sea surface temperature anomaly of the Barents Sea elevated in the October, the sea-level pressure anomaly elevated in eastern China and northeastern China winter, the absolute value of correlation coefficient
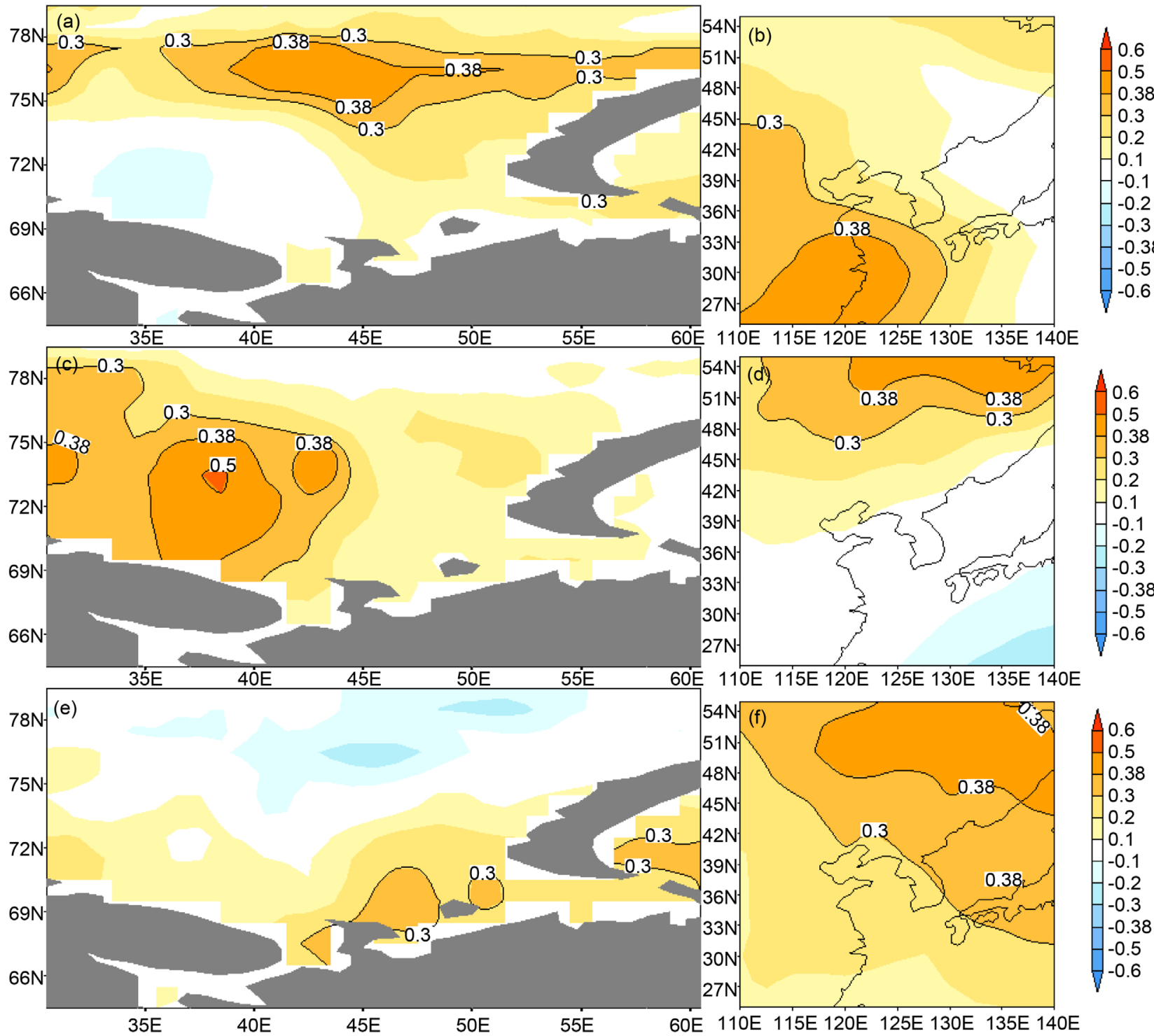

Figure 2. The hetero-correlation coefficient fields of the first SVD mode between the Barents Sea (in the west of Novaya Zemlya) SSTA (in October, (a) (c) (e)) and China east coast SLPA (in December, January and February, (b) (d) (f)). 
and the affected area were more significant than other months. Therefore, the Barents Sea SST in autumn can be used as an important reference factor for predicting the cold air activity in China.

\subsection{Impact of the Barents Sea SSTA in Autumn on Winter Air Circulation}

Considering the actual value and timeliness of the climate prediction, we chose the years in which the Barents Sea SSTA in October was significantly positive: 1950, 1953, 1954, 1955, 1961, 1963, 1983, 1989, 1990, 2000, 2007, 2008, 2011, and significantly negative SSTA years: 1948, 1956, 1960, 1966, 1968, 1978, 1981, 1993, 1998, to compose winter (12 - 2 months) geopotential height anomaly field, wind anomaly field at $500 \mathrm{hPa}$ and $1000 \mathrm{hPa}$ (Figure 3).

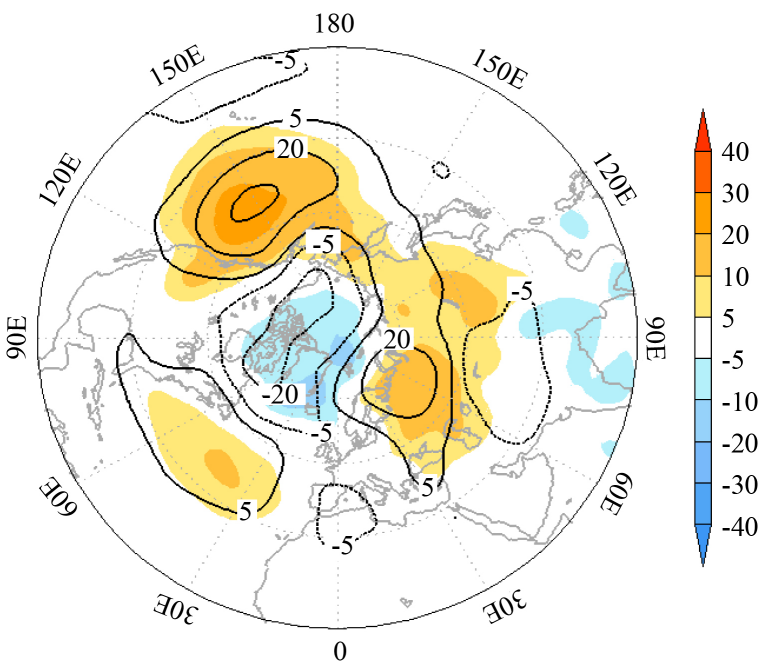

(a)

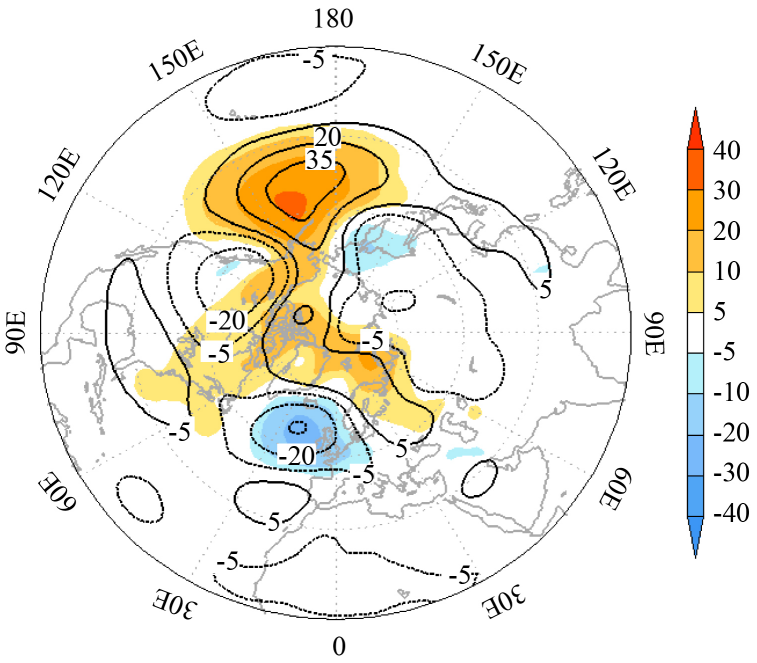

(b)

Figure 3. The composite winter geopotential height anomaly of $500 \mathrm{hPa}$ (contour) and $1000 \mathrm{hPa}$ (shaded) over Northern Hemisphere in (a) positive and (b) negative SSTA years in Barents Sea in October. 
There were differences between significantly positive SSTA years and significantly negative SSTA years in October: In positive SSTA year, the west of the Ural Mountains appeared geopotential height positive anomaly at $500 \mathrm{hPa}$ and the abnormal high-pressure ridge developed, and areas with geopotential height negative anomaly at $500 \mathrm{hPa}$ became narrow and southward with weakened intensity (Figure 3(a)); in negative SSTA years, areas with geopotential height positive anomaly at $500 \mathrm{hPa}$ became narrow and westward with weakened intensity, while areas with geopotential height negative anomaly at $500 \mathrm{hPa}$ increased and became westward and northward (Figure 3(b)); compared with the negative SSTA years, the geopotential height over Eastern Europe, Russia at $500 \mathrm{hPa}$ appeared positive anomaly, while the Mongolia high-pressure increased and the northerly airflow strengthened the cold high-latitude air broke out to the south in the positive SSTA years.

\section{Summary}

1) The Barents Sea SSTA in early autumn (October) has good persistence and can last until late spring.

2) When the Barents Sea SSTA elevated in the autumn, the sea-level air pressure anomaly elevated in eastern China on December, northeast China and southeastern Russia on January and February. Therefore, the Barents Sea SST in autumn can be used as an important indicator of predicting the cold air activity in China.

3) In the years when the SSTA of the Barents Sea elevated in the autumn, the abnormal high-pressure ridge developed over Europe, and the geopotential height in western China appeared negative anomaly at $500 \mathrm{hPa}$; at $1000 \mathrm{hPa}$, the Mongolia high-pressure increased and the northerly airflow strengthened the cold high-latitude air broke out to the south, which was easy to affect northeast and north of China. In negative SSTA years, the high-pressure ridge was west to the north Atlantic, and the geopotential height in central and northern Siberia appeared negative anomaly at $500 \mathrm{hPa}$; the Mongolia high-pressure was weakened at $1000 \mathrm{hPa}$.

\section{Acknowledgements}

The authors thank Prof. Qinyu Liu for her suggestions about the persistence of the SSTA. This work was supported by Qingdao Bureau Research Subject for Youth (2016qdqxq9) and the Innovation and Research Foundation of Ocean University of China (No. 201261009).

\section{References}

[1] Shi, X.M., Sun, J.L., Wu, D.X. and Wei, D.N. (2015) Impact of Autumn SST in the Japan Sea on Winter Rainfall and Air Temperature in Northeast China Area. Journal of Ocean University of China, 14, 604-611. https://doi.org/10.1007/s11802-015-2477-4

[2] Shi, X.M., Sun, J.L., Sun, Y.W., Bi, W., Zhou, X. and Yi, L. (2015) The Impact of the 
Autumn Atlantic Sea Surface Temperature There-Pole Structure on Winter Atmospheric Circulation. Haiyang Xuebao, 37, 33-40.

[3] Shi, X.M. (2014) The Impact of the Mid-High Latitude Oceans on Climate Change over North and Northeast China. PHD Thesis of Ocean University of China.

[4] Xie, X.H. and Yang, X.Q. (2006) Interannual Relationship between Arctic Sea Ice Concentration Anomaly and China Air Temperature Variation during Winter. Journal of Nanjing University (Natural Sciences), 42, 549-561.

[5] Zhu, Q.G., Lin, J.R., Shou, S.W. and Tang, D.S. (2007) Principle of Synoptic Meteorology. China Meteorological Press, 267.

[6] Wu, B.Y. and Huang, R.H. (1999) Effects of the Extremes in the North Atlantic Oscillation on East Asia Winter Monsoon. Chinese Journal of Atmospheric Sciences, 641-651.

[7] Wu, B.Y., Huang, R.H. and Gao, D.Y. (2001) Numerical Simulations on Influence of Sea-Ice Thickness and Extent Variation in Arctic on Atmospheric Circulation. Acta Meteorologica Sinica, 59, 414-428.

[8] Wu, B.Y., Bian, L.G. and Zhang, R.H. (2004) Effects of the Winter AO and the Arctic Sea Ice Variations on Climate Variation over East Asia. Chinese Journal of Polar Research, 16, 211-220.

[9] Wu, B.Y., Su, J.Z. and Zhang, R.H. (2011) Effects of Autumn-Winter Arctic Sea Ice on Winter Siberian High. Chinese Science Bulletin, 56, 3220-3228.

https://doi.org/10.1007/s11434-011-4696-4

Submit or recommend next manuscript to SCIRP and we will provide best service for you:

Accepting pre-submission inquiries through Email, Facebook, LinkedIn, Twitter, etc. A wide selection of journals (inclusive of 9 subjects, more than 200 journals)

Providing 24-hour high-quality service

User-friendly online submission system

Fair and swift peer-review system

Efficient typesetting and proofreading procedure

Display of the result of downloads and visits, as well as the number of cited articles

Maximum dissemination of your research work

Submit your manuscript at: http://papersubmission.scirp.org/

Or contact gep@scirp.org 